\title{
La belle indifférente
}

Nicole Jolicoeur

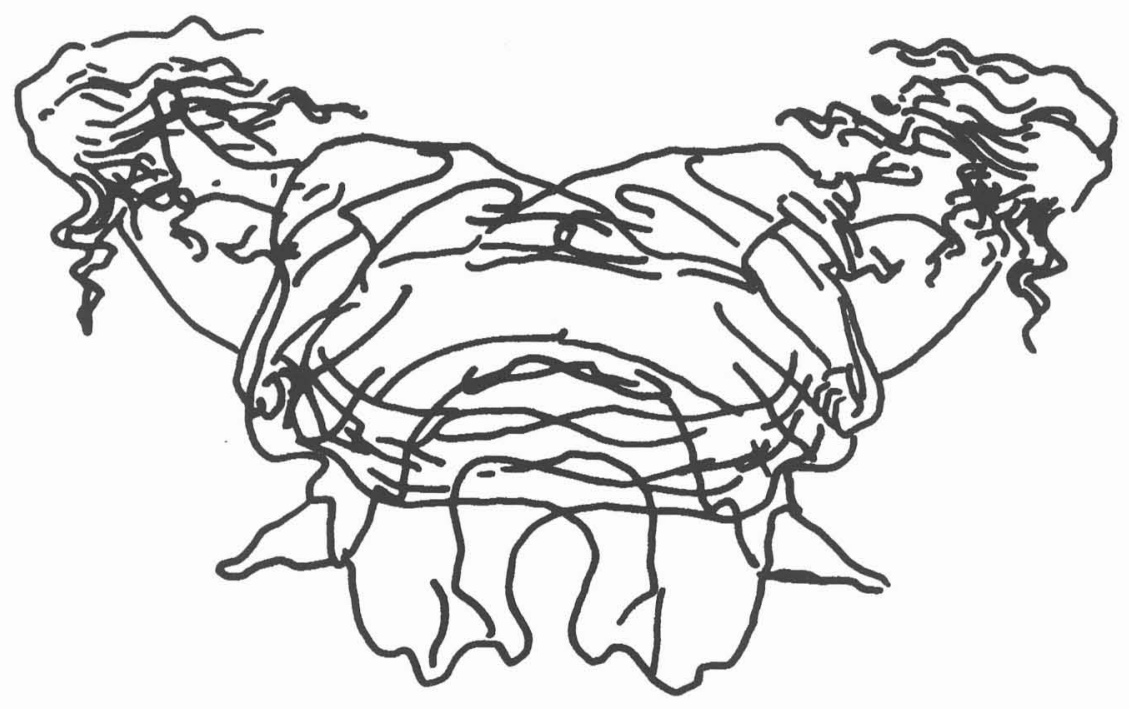


48. Tessera

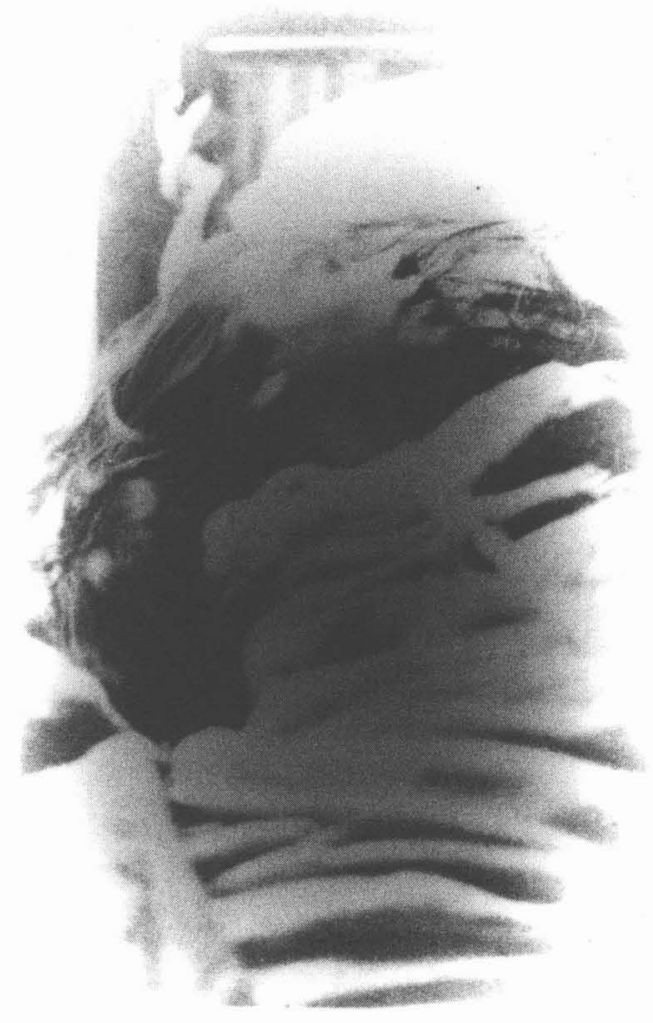


La belle indifférente · 49

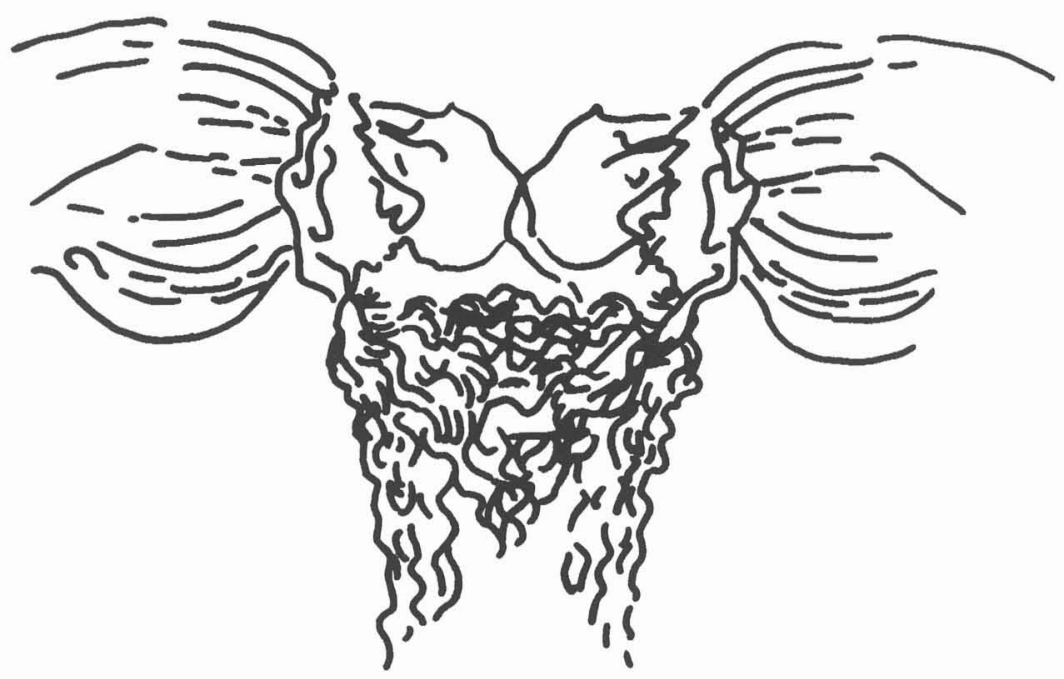


50. Tessera

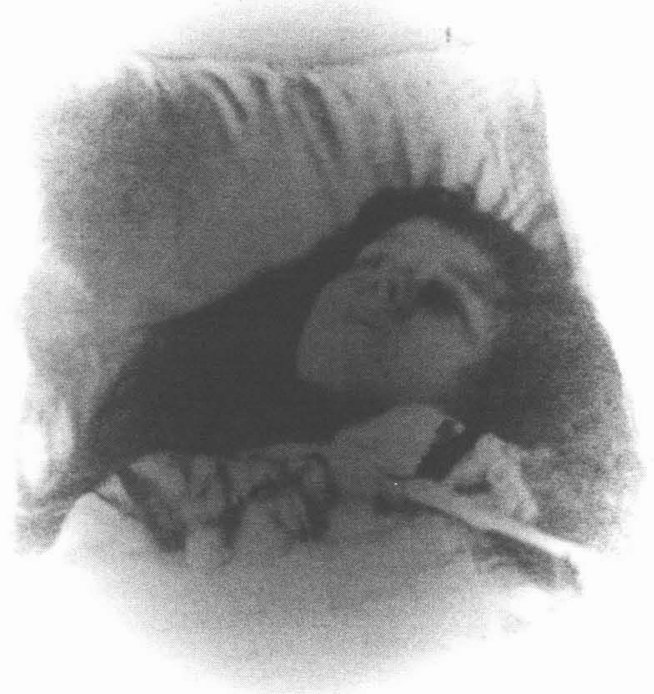

